\title{
hrp Genes of Erwinia chrysanthemi 3937 Are Important Virulence Factors
}

\author{
Ching-Hong Yang, ${ }^{1}$ Marina Gavilanes-Ruiz, ${ }^{2}$ Yasushi Okinaka, ${ }^{1}$ Regine Vedel, ${ }^{3}$ Isabelle Berthuy, ${ }^{3}$ \\ Martine Boccara, ${ }^{3}$ Jason Wei-Ta Chen, ${ }^{1}$ Nicole T. Perna, ${ }^{4}$ and Noel T. Keen ${ }^{1}$ \\ ${ }^{1}$ Department of Plant Pathology, University of California, Riverside, CA 92521 U.S.A.; ${ }^{2}$ Departamento de Bioquímica, \\ Facultad de Química, Conj. E. UNAM. Cd. Universitaria, Coyoacán, México 04510 D.F. México; ${ }^{3}$ Laboratoire de pathologie \\ végétale, UMR 217 INRA-INAP/G-Paris 6, 16 rue Claude Bernard, 75005 Paris, France; ${ }^{4}$ Department of Animal Health \\ and Biomedical Sciences, University of Wisconsin, Madison, WI 53706 U.S.A.
}

Submitted 5 October 2001. Accepted 4 January 2002.

\begin{abstract}
We developed improved virulence assays for Erwinia chrysanthemi 3937 on African violet varieties and devised a new method for the construction of precise bacterial gene knockouts. These methods were tested by constructing mutations in genes suspected to be involved with plant interactions. The virulence of the $h r p G$ and $h r c C$ mutant strains (both gene products presumed to be involved in protein secretion) was greatly reduced on leaves of semitolerant African violet varieties. An $h r p N$ mutant strain produced delayed symptoms on African violet leaves and an hrpN $\Delta p e l$ $(\Delta p e l=$ five major pectate lyase genes deleted $)$ double mutant was nonpathogenic. The $h r c C$ and $h r p G$ mutants did not produce a rapid hypersensitive response (HR) in tobacco, unlike the wild-type bacterium, and the $h r p N$ mutant gave a reduced $H R$. The results, therefore, establish the importance of $h r p$ genes in the virulence of $E$. chrysanthemi and their ability to elicit HR on nonhosts. The data also suggest that other effector proteins secreted by the Hrp system are required for full virulence and HR elicitation.
\end{abstract}

Additional keywords: bacterial plant pathogens, barcode, crossover, polymerase chain reaction, type III secretion pathway.

Erwinia chrysanthemi is a host-promiscuous necrotrophic pathogen in which the production of pectic enzymes and siderophore-dependent iron uptake systems are considered to be major pathogenicity factors (Franza et al. 1999; RobertBaudouy et al. 2000). At least eight endo-pectate lyases (PelA, PelB, PelC, PelD, PelE, PelI, PelL, and PelZ), two exo-pectate lyases (PelX and PelW), two pectin methylesterases (PemA and PemB), and a pectin acetyl-esterase (PaeY) are produced by $E$. chrysanthemi. However, individual pectic enzymes have different roles in virulence, depending on the host plant. For example, pelA, pelD, pelE and the pem genes were essential for full expression of $E$. chrysanthemi virulence on African

Corresponding author: Noel T. Keen; Telephone: +1.909.787.4134; Fax: +1.909.787.4294; E-mail: keen@ucrac1.ucr.edu

Current address of Isabelle Berthuy: CNRS UMR8602, Faculté de Médecine Necker, 156 rue de Vaugirard, 75015 Paris, France.

Nucleotide sequence data reported are available in the GenBank database under the accession numbers AF411590 and HX976548487 for Erwinia chrysanthemi 3937 hrpG and $h r p N$, respectively. violet (Saintpaulia ionantha). The pem genes and all pel genes, except pelE, were needed for full virulence on chicory leaves (Beaulieu et al. 1993; Robert-Baudouy et al. 2000).

Surprisingly, mutations in the type III $h r p$ gene secretion system have not been observed to seriously reduce the virulence of $E$. chrysanthemi (Bauer et al. 1994; López-Solanilla et al. 2001) or E. carotovora (Rantakari et al. 2001). hrp Genes are present in many phytopathogenic bacteria and encode proteins that constitute the type III secretion systems required for elicitation of defensive hypersensitive responses (HR) on nonhost plants and pathogenicity on host plants (Alfano and Collmer 1997; Alfano et al. 1996; Barny 1995; Charkowski et al. 1998; Galan and Collmer 1999; He 1998; $\mathrm{Hu}$ et al. 2001; Hueck 1998; Kim et al. 1997). Relatively little is known about proteins that are translocated by the hrp gene system in bacterial plant pathogens. The $h r p N$ and $d s p E$ proteins of E. amylovora and E. carotovora subsp. carotovora and PopA1 of Ralstonia solanacearum elicit HR-like necrosis in nonhost plant leaves and are hrp secreted (Arlat et al. 1994; Bogdanove et al. 1998; Cui et al. 1996; Gaudriault et al. 1997; Kim et al. 1997).

The apparent minimal role for hrp genes in E. chrysanthemi may have been exacerbated by the lack of stringent host plants available for virulence assays. To further address these and other questions, the availability of suitable virulence assays is crucial. We describe the development of a crossover polymerase chain reaction (PCR) method for introducing precise gene knockouts into E. chrysanthemi 3937 and the identification of African violet varieties with varying disease tolerance. We also show that $h r p N$ contributes to virulence and present the first report of large virulence penalties resulting from mutation of the E. chrysanthemi hrpG or $h r c C$ genes, presumed to be involved in the type III translocation of effector proteins.

\section{RESULTS}

Construction of mutant strains.

We took advantage of the sensitivity of E. chrysanthemi 3937 to $\mathrm{Mu}$ phage in order to construct mutants in the hrpN and $h r c C$ genes by using a phage $\mathrm{Mu}:$ :lacZ derivative, MuDIIPR13 (Ratet et al. 1988). Plasmids pCPN2 and p2AC1, containing the $h r p N$ gene and the $h r c C$ genes, respectively, were introduced into JM109(MuPR13) for miniMu transposon mutagenesis. Different miniMu insertions were analyzed by restriction mapping, some were sequenced with a $\mathrm{Mu}$ end primer 
and the pRVA5 and pRVC112 insertions were retained. The insertion in pRVA5 was located at nucleotide 376 of the $h r p N$ gene and the insertion in pRV85, which interrupted the hrcC gene, was identified at nucleotide 1,421 . Both constructs were marker-exchanged into E. chrysanthemi 3937 . The generated strains were called PMVA5 and PMVC112, respectively (Table 1). In addition, transduction with phage $\Phi E C 2$ was used to transfer the PMVA5 hrpN mutation into the $\Delta p e l$ strain (PMV4116) to generate the double mutant PMVM4.

Marker-exchange gene knockout mutants of E. chrysanthemi 3937 were also constructed by the crossover PCR strategy outlined in Figure 1 and described below. It is not necessary to have the cloned target gene as long as its sequence and that of approximately 500 base pairs (bp) to 1 kilobases $(\mathrm{kb})$ of flanking DNA on both sides are known. As such, the methodology will be particularly useful as an adjunct for constructing null mutants in the impending E. chrysanthemi genome-sequencing project. To test the gene knockout methodology, we initially constructed mutants in genes known to be involved in E. chrysanthemihost interactions. A large deletion mutation, involving excision of approximately $5 \mathrm{~kb}$ from the pelA-pelE-pelD-paeY-pemA region of strain 3937 (Shevchik and Hugouvieux-Cotte-Pattat 1997), was constructed, indicating that the technology may be useful for the construction of large deletions. Single open reading frame $(\mathrm{ORF})$ deletions were also constructed in the strain
$3937 \mathrm{hrpG}$ and $h r p N$ genes. Introduction of the cloned wildtype genes into the mutant strains restored the wild-type phenotypes, as discussed later, indicating that these mutations are nonpolar.

Attempts to directly electroporate the final linear mutagenic PCR products from Figure 1 into strain 3937 cells and select desired mutants were unsuccessful. It was, therefore, necessary to clone the mutagenic PCR products and introduce resulting plasmid constructs into the bacterium. We used the $s a c B$-containing plasmid, $\mathrm{pKO}_{3}$ (Link et al. 1997) (Table 1), for construction of the mutations noted above. This plasmid permits growth of transformants on 5\% sucrose medium in order to select double recombinants and counterselect against uncured bacterial cells. However, the use of $\mathrm{pKO}_{3}$ necessitated an extra cloning step and did not always afford clean curing from strain 3937, thus failing in some instances to provide desired gene knockouts (C.-H. Yang, M. Gavilanes-Ruiz, and N. T. Keen, unpublished data).

Mutants from the crossover PCR strategy were identified by isolation of colonies that were kanamycin resistant and chloramphenicol sensitive. The mutants were verified by determination of fragment sizes across the mutated regions by using PCR with isolated chromosomal DNA. The predicted wildtype/mutant junctions were also confirmed by sequencing the integration site of each mutant.

Table 1. Strains, plasmids, and DNA primers used in this study

\begin{tabular}{|c|c|c|}
\hline $\begin{array}{l}\text { Strains, plasmids, and primers } \\
\end{array}$ & Characters or sequences $\left(5^{\prime} \text { to } 3^{\prime}\right)^{\mathrm{a}}$ & Reference or source \\
\hline \multicolumn{3}{|l|}{ Erwinia chrysanthemi strains } \\
\hline 3937 & Wild type & $\begin{array}{l}\text { Hugouvieux-Cotte-Pattat and } \\
\text { Robert-Baudouy } 1985\end{array}$ \\
\hline L37 & $\mathrm{Lac}^{-}$mutant strain & $\begin{array}{l}\text { Hugouvieux-Cotte-Pattat and } \\
\text { Robert-Baudouy } 1985\end{array}$ \\
\hline 3937 hrc C mutant & Insertion mutation & This work \\
\hline 3937 hrpG mutant & Crossover polymerase chain reaction (PCR) deletion mutant & This work \\
\hline 3937 hrpN mutant PMVA5 & Deletion mutant & This work \\
\hline 3937 hrpN mutant $h r p N:: \mathrm{km}$ & Crossover PCR deletion mutant & This work \\
\hline 3937 pelA-pemA mutant & Crossover PCR deletion mutant & This work \\
\hline 3937 spel strain PMV4116 & Mutated for the pelA, pelB, pelC, pelD, and pelE genes & Beaulieu et al. 1993 \\
\hline 3937 spel hrpN strain PMVM4 & Mutated for the pelA, pelB, pelC, pelD, pelE, and $h r p N$ genes & This work \\
\hline \multicolumn{3}{|l|}{ Plasmids } \\
\hline pBBR1MCS-2 & Broad-host-range cloning vector, $\mathrm{Km}^{\mathrm{r}}$ & Kovach et al. 1995 \\
\hline $\mathrm{pKO}_{3}$ & Gene-replacement vector, $\mathrm{Cm}^{\mathrm{r}}$ & Link et al. 1997 \\
\hline pGEM-T Easy & PCR cloning vector, $\mathrm{Ap}^{\mathrm{r}}$ & Promega, Madison, WI, U.S.A. \\
\hline pRK415 & Broad-host-range cloning vector, $\mathrm{Tc}^{\mathrm{r}}$ & Keen et al. 1988 \\
\hline pPel & $\begin{array}{l}\text { pGEM-T Easy containing the pectate gene cluster, pelA, pelE, pelD, paeY, and pemA, } \\
\text { of E. chrysanthemi } 3937\end{array}$ & This study \\
\hline pRK415:hrpG & 1.6-kb DNA fragment in pRK415 containing $h r p G$ with its own promoter & This study \\
\hline \multicolumn{3}{|l|}{ Primers } \\
\hline HrpG A & GTCGACGGATAACCCGCAAAAACCGG & \\
\hline HrpG B & $\begin{array}{l}\text { TAATAATGAACGAGCACACCCCGAGAGACCTCGTGGACATCAGTTGAAGTCATT } \\
\text { GATGATGGCCTTC }\end{array}$ & \\
\hline HrpG C & $\begin{array}{l}\text { GGTGTGCTCGTTCATTATTAGCACCTACGCTCTCCCGATGAGGCGCGCCCAGCAT } \\
\text { GCGTAACGCGCTGTATGCAC }\end{array}$ & \\
\hline HrpG D & CCAGGGATCACCAGGCGTTGATCGCG & \\
\hline HrpN A & TCGCTCGTCGTTATCAGCAG & \\
\hline HrpN B & $\begin{array}{l}\text { GTAAACCGGGAAAGCCGCAACCGAGAGACCTCGTGGACATCTCAGTTTATCCAC } \\
\text { GCTGG }\end{array}$ & \\
\hline $\mathrm{HrpN} \mathrm{C}$ & TTGCGGCTTTCCCGGTTTACGGCGCGCCTCGGC GATAAAATAGCCAAC & \\
\hline HrpN D & ATGGAGAAAGATGATGACGAAC & \\
\hline P1 & ATGCAAATTACGATCAAAGCGC & \\
\hline P2 & GGTAAGCTGGCCGCCAACGCCTG & \\
\hline PelA B & TGGTTGCGGGTCGCGTGTTCGTGCTGATCGAACAGGCTGTTGGAGA & \\
\hline PemA C & GAACACGCGACCCGCAACCAGGCGCGCCTCCGACTGCCGTATCAGCGGCACGG & \\
\hline Pelfor1 & ATCCAGATCACAGGCACGGTCG & \\
\hline Pelrev1 & TTTGCTCTGCGTGTACTCTGCC & \\
\hline Kmfor & GGCGCGCCTTTGTTCCCTTTAGTGAGGGTTAATT & \\
\hline KmU2for & GGCGCGCCGCACCTACGCTCTCCCGATGATTTGTTCCCTTTAGTGAGGGTTAATT & \\
\hline Kmrev & GGCGCGCCCCTGGGATGAATGTCAGCTACTGGGC & \\
\hline
\end{tabular}

${ }^{\mathrm{a}} \mathrm{Ap}=$ ampicillin, $\mathrm{Cm}=$ chloramphenicol, $\mathrm{Km}=$ kanamycin, $\mathrm{Lac}=$ lactose-fermenting derivatives, and $\mathrm{Tc}=$ tetracycline. 


\section{Virulence assays.}

Decreased maceration of potato tuber slices relative to the wild type was observed with the pelA-pemA deletion mutant of $E$. chrysanthemi 3937. Pronounced and indistinguishable maceration of potato tuber tissue was observed with the wild-type bacterium and the $h r p G$ and $h r p N$ mutants. When wild-type E. chrysanthemi 3937 and the pelA-pemA, hrpG, and hrpN mutants were grown on YC plates (Casamino Acids, yeast extract) and flooded with $1 \mathrm{M} \mathrm{CaCl}_{2}$ (Keen et al. 1984), a significant reduction in the size of halos was only observed with the pelA-pemA mutant (data not shown). The pelA-pemA deletion mutant of $E$. chrysanthemi 3937 produced slower initial maceration of African violet leaves, but no significant difference in ultimate maceration was observed compared with the wild-type bacterium with disease-susceptible or -tolerant varieties (data not shown).

Compared with potato tubers, African violet is a more stringent host for E. chrysanthemi 3937 and is the host from which the bacterium was initially isolated (LeMattre and Narcy 1972). From the nine different varieties of African violet tested against the wild-type bacterium, Irene, Maki, Katja, Marylin, and Jennie (disease index [DI] > 3.0) were classified as disease susceptible, while Rosalie, Manitoba, Van Gogh, and Patsy (DI < 3.0) were disease tolerant (Table 2). These results indicated that these varieties would be useful in order to investigate bacterial mutants for virulence defects.

The type III secretion pathway of $E$. chrysanthemi 3937 is important for virulence on a disease-tolerant host.

It is considered difficult to reliably study the population dynamics of $E$. chrysanthemi in susceptible plant tissues because of the dominant effect of pectic enzymes. In our experiments, none to slightly visible leaf maceration was observed in variety Katja 7 days after $10^{6}$ CFU of wild-type E. chrysanthemi 3937 per $\mathrm{ml}$ was infiltrated, but significant bacterial multiplication occurred. This system accordingly offered the possibility of reliably monitoring bacterial cell multiplication as a criterion of virulence. As expected, similar bacterial populations were found in excised leaf disks (approximately $10^{4} \mathrm{CFU} / \mathrm{cm}^{2}$ ) at day 0 with both the wild-type and $h r p G$ mutant strains of $E$. chrysanthemi 3937 (Fig. 2A). Seven days after inoculation, the population of wild-type bacteria had increased more than 100fold, but populations of the $h r p G$ mutant declined to almost undetectable levels.

Using the disease-tolerant varieties, no symptoms or very slight maceration only at the inoculation site were observed with the $h r p G$ mutant (DIs ranging from 0 to 0.6 at 7 days after inoculation). However, DIs ranging from 1.9 to 3.0 were found in these varieties inoculated with the wild-type bacterium. In disease-susceptible varieties, the $h r p G$ mutant was able to produce moderate to severe macerations symptoms on Irene, Maki, and Jennie but had reduced infection ability on Katja and Marylin. The hrpG mutant caused wild-type disease symptoms in variety Katja when the cloned $h r p G$ gene, with its own promoter (pRK415:hrpG), was introduced into the mutant strain (Fig. 3B). This suggests that the crossover PCR mutagenesis strategy does not produce polar effects on the expression of downstream genes organized as operons. The $h r c C$ mutant of E. chrysanthemi 3937 also led to greatly reduced virulence on variety Katja (Table 3), similar to the hrpG strain. This is per-

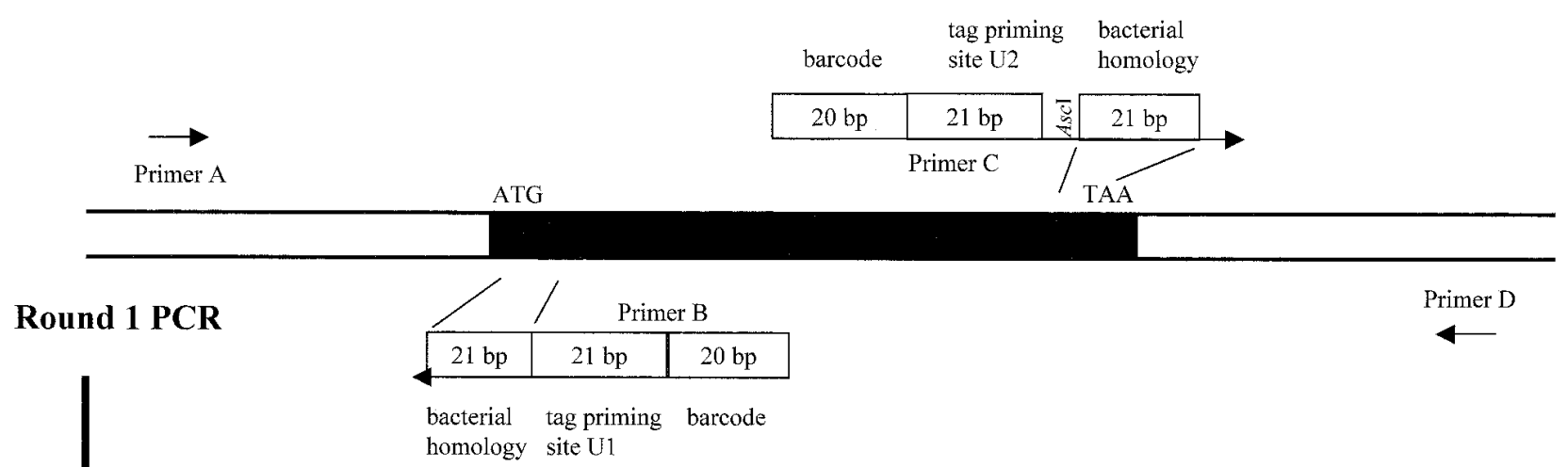

PCR1 (Primers A \& B)

PCR2 (Primers C \& D)
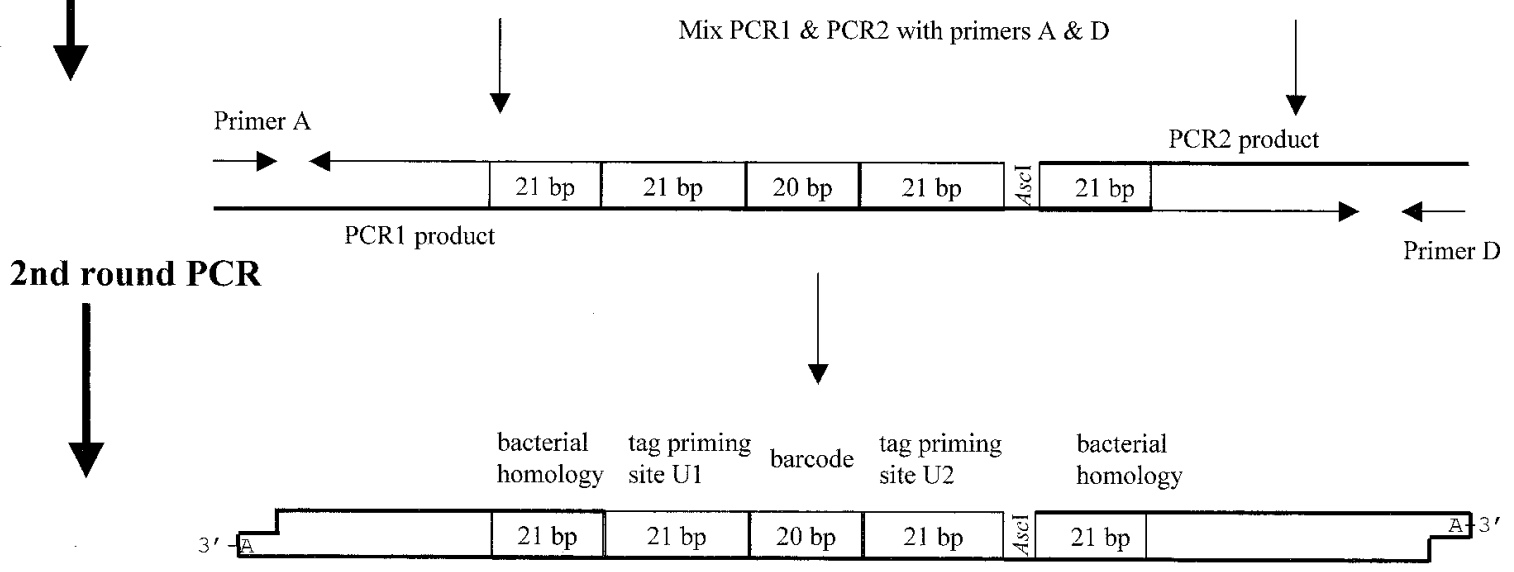

Fig. 1. Preparation of mutagenic constructs for use in the crossover polymerase chain reaction (PCR) gene knockout strategy with Erwinia chrysanthemi 3937. Double lines at the top denote the target gene in chromosomal DNA, with the ATG translational start and TAA terminators shown. Four specific primers are constructed, with primers $\mathrm{A} / \mathrm{B}$ and $\mathrm{C} / \mathrm{D}$ targeted to homologous regions approximately $500 \mathrm{bp}$ to $1 \mathrm{~kb}$ apart on the genomic sequences. Second-round PCR involves the annealing of the 20-bp barcode sequences of PCR products A/B and C/D and employing primers A and D to produce the final mutagenic construct, $\mathrm{A} / \mathrm{D}$. 
haps to be expected, since both gene products are believed to facilitate the secretion of effector proteins (Yuan et al. 2000). Our results therefore demonstrate that the type III secretion pathway of E. chrysanthemi is required for full pathogenicity in disease-tolerant varieties.

\section{Virulence of the $h r p N$ mutant strains.}

Slightly reduced virulence (as determined by visual observation of symptoms) was observed with the $h r p N$ mutant strains when using disease-susceptible and -tolerant African violet varieties (Fig. 3; Tables 2 and 4). Population levels of the hrpN mutants were only slightly reduced after 7 days in African violet leaves, relative to the wild type (Fig. 2B). These results mirrored the visible symptoms observed when higher bacterial inoculation densities were employed (Figs. 2 and 3) and indicate that bacterial population levels can be followed as a quantitative measure of bacterial virulence. Moreover, a delay in symptom appearance with the $h r p N$ insertion mutant (PMVA5) (Table 4) was observed. The $\Delta$ pel strain (PMV4116), although considerably reduced in virulence, produced some maceration of inoculated leaves (Table 4). In contrast, the $\Delta p e l$ hrpN double mutant (PMVM4) produced only occasional leaf maceration, which did not develop further (Table 4). The results accordingly suggest that the role of $h r p N$ in virulence is masked in the presence of the major pel genes of E. chrysanthemi.

\section{The $h r c C, h r p G$, and $h r p N$ mutants are reduced in their ability to elicit HR in tobacco leaves.}

Confirming Shevchik and colleagues (1998), strong and indistinguishable HR were observed within $16 \mathrm{~h}$ in Nicotiana tabacum L. cv. Xanthi by E. chrysanthemi 3937 wild-type cells and the pelA-pemA mutant (Fig. 4). No HR was observed on tobacco leaves when the strain $3937 \mathrm{hrcC}$ and $h r p G$ mutants were infiltrated for the same time, but a slight HR was observed with the $h r p N$ mutant. The $h r c C, h r p G$, and $h r p N$ mutants all produced partial HR necrosis in tobacco leaves after $24 \mathrm{~h}$ (data not shown).

\section{DISCUSSION}

E. chrysanthemi is often described as a brute-force pathogen, since it produces an array of pectic and other enzymes that cause rapid maceration of plant tissues. Although type III secretion genes have been identified in E. chrysanthemi, available hosts did not previously reveal significant virulence differences of the hrp mutant strains from the wild type (Bauer et al. 1994; Kim et al. 1998; López-Solanilla et al. 2001). A major

Table 2. Virulence of Erwinia chrysanthemi 3937 wild-type and $h r p N$ $(h r p N:: \mathrm{km})$ and $h r p G$ mutant strains in leaves of nine varieties of African violet at 7 days after inoculation

\begin{tabular}{|c|c|c|c|c|c|}
\hline \multirow[b]{2}{*}{ Variety $^{\mathbf{a}}$} & \multirow{2}{*}{$\frac{\text { Wild-type }}{\text { DI }^{\mathbf{b}}}$} & \multicolumn{2}{|c|}{ hrpN mutant } & \multicolumn{2}{|c|}{ hrp $G$ mutant } \\
\hline & & DI & DI ratio ${ }^{\mathrm{c}}$ & DI & DI ratio ${ }^{c}$ \\
\hline Irene & 4.5 & 3.8 & 0.84 & 2.9 & 0.64 \\
\hline Jennie & 3.3 & 2.2 & 0.61 & 2.2 & 0.67 \\
\hline Maki & 3.9 & 3.9 & 1.0 & 1.7 & 0.44 \\
\hline Katja & 4.6 & 3.5 & 0.76 & 0.7 & 0.15 \\
\hline Marylin & 3.6 & 1.5 & 0.42 & 0.6 & 0.17 \\
\hline Rosalie & 3.0 & 1.9 & 0.63 & 0.3 & 0.1 \\
\hline Manitoba & 2.3 & 1.4 & 0.61 & 0.6 & 0.26 \\
\hline Van Gogh & 2.6 & 1.5 & 0.58 & 0.1 & 0.04 \\
\hline Patsy & 1.9 & 0.7 & 0.37 & 0.0 & 0.0 \\
\hline
\end{tabular}

${ }^{\mathrm{a}}$ Five plants with a total of 10 leaves were used for each bacterial isolate.

${ }^{\mathrm{b}}$ The disease index (DI) was scored as follows: $0=$ no maceration symptoms, $1=$ less than $20 \%$ maceration of the total leaf, $2=20$ to $39 \%, 3=$ 40 to $59 \%, 4=60$ to $79 \%$, and $5=80$ to $100 \%$.

${ }^{\mathrm{c}}$ DI ratio $=$ DI of mutant/DI of wild-type bacterium. finding in this work was that considerable variation exists in the disease susceptibility of various African violet varieties. On all disease-tolerant African violet varieties tested (Rosalie, Manitoba, Van Gogh, and Patsy), the hrp translocation gene mutants ( $h r c C$ and $h r p G$ ) were severely reduced in virulence relative to the wild type. When assayed on the susceptible varieties Katja and Marylin, the type III secretion system was also required for high bacterial virulence. In leaves of the susceptible varieties Irene, Jennie, and Maki, however, the hrpG mutant of strain 3937 produced significant disease, similar to the hrp gene mutants assayed on other plants (Bauer et al. 1995). These variety differences are interesting, disclosing differential variety interactions with the $h r p G$ mutant and suggesting that the latter varieties are relatively nonstringent hosts. This conclusion is supported by the observation that maceration of potato tuber pieces by the $h r p G$ mutant and wild-type strain 3937 were indistinguishable. The results are also consistent with the prevailing view that detection of virulence defect phenotypes is more difficult on nonstringent hosts and that pectic enzymes from $E$. chrysanthemi may be sufficient to confer nearly full virulence in such cases. Comparison of the major reduction in virulence for the $h r c C$ and $h r p G$ mutants with the minor reduction for the $h r p N$ mutants also suggests that other unidentified $h r p$-translocated virulence factors are present in E. chrysanthemi 3937. It is significant, however, that in the $\Delta p e l$ strain, a second $h r p N$ mutation led to a great reduction

A

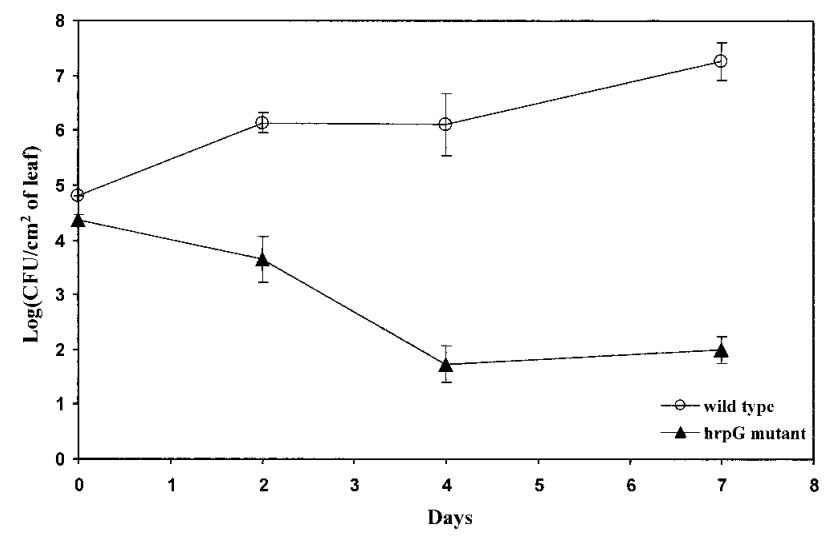

B

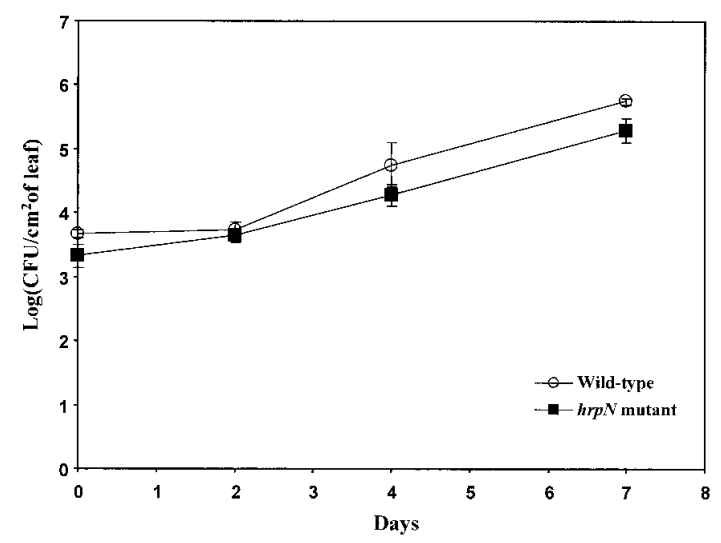

Fig. 2. A, Growth of wild-type Erwinia chrysanthemi 3937 and a $h r p G$ mutant strain in African violet variety Katja leaves. B, Growth of wildtype E. chrysanthemi 3937 and the $h r p N(h r p N:: \mathrm{km})$ mutant in African violet variety Katja leaves. Leaves were infiltrated with bacterial suspensions $\left(10^{6} \mathrm{CFU} / \mathrm{ml}\right)$ with a $1-\mathrm{ml}$ plastic syringe. Eight leaves from eight replicate plants were used at each sampling time for each bacterial strain, with error bars shown. 
in virulence. This confirms the effect of pectic enzymes in partially complementing the effects of the hrp gene system, as reported by previous workers (Bauer et al. 1994).

Using low cell densities, we were able to monitor bacterial populations in African violet leaves as a quantitative measure of virulence. This assay clearly showed a $h r p G$ defect for growth in the plant (Fig. 2A). The fact that the hrpN mutant multiplied to almost the same level as the wild-type bacteria (Fig. 2B) confirms results of symptom evaluations in suggesting that this gene has a minor role in virulence. The ability to monitor cell populations in African violet leaves should enhance the ability to detect other minor virulence-associated genes in strain 3937. Compared with disease-susceptible Afri- can violet varieties, reduced maceration symptoms were observed when the wild-type bacteria were inoculated into leaves of disease-tolerant varieties. The bases for these differences are unknown. Compared with the wild-type bacteria, the $h r p G$ mutant also multiplied less in leaf tissue of the tolerant varieties and caused little maceration. Since production of pectic lyases by $E$. chrysanthemi is dependent on quorum sensing (Nasser et al. 1998; Reverchon et al. 1998), it is reasonable to speculate that a synergistic effect may be present between type III virulence effectors and pectic enzymes.

Similar to observations by Shevchik and colleagues (1998), the pelA-pemA mutant strain of E. chrysanthemi 3937 produced HR necrosis indistinguishable from that of the wild type

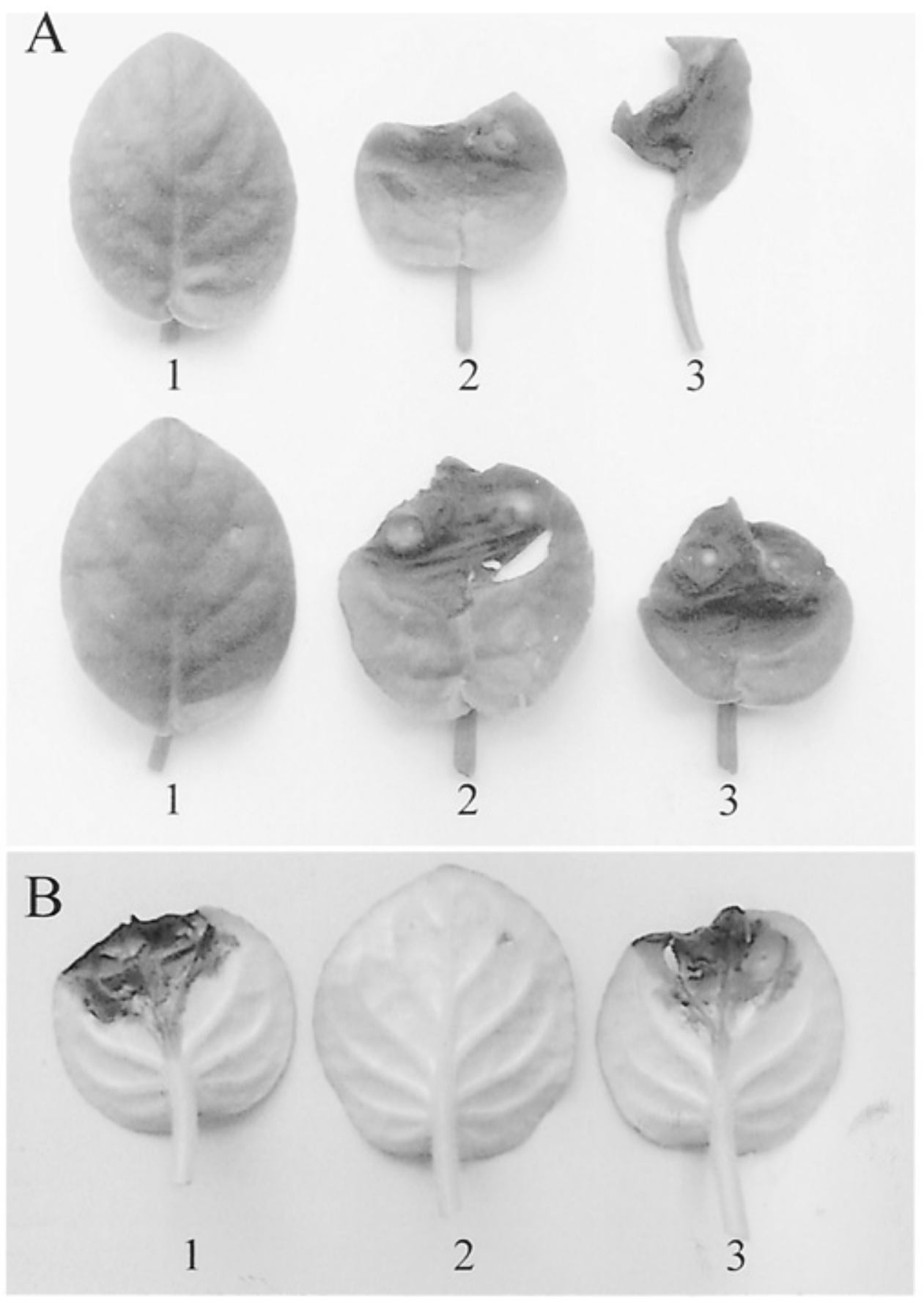

Fig. 3. Representative disease lesions caused by wild-type Erwinia chrysanthemi 3937 and its hrpG or hrpN mutants on leaves of African violet variety Katja. A, $1=h r p G$ mutant, $2=h r p N(h r p N:: \mathrm{km})$ mutant, and 3 = wild-type E. chrysanthemi 3937. Leaves, two shown for each treatment, were photographed at 7 days after inoculation. B, $1=$ wild-type E. chrysanthemi $3937,2=h r p G$ mutant, and $3=h r p G$ mutant complemented with pRK415:hrpG. Leaves photographed at 5 days after inoculation. 
on tobacco leaves. However, the $h r c C$ and $h r p G$ mutants did not produce visible HR on tobacco leaves within $16 \mathrm{~h}$ after inoculation (Fig. 4), confirming the loss of the type III secretion function in this strain. Interestingly, the $h r p N$ mutant produced only a slight HR on tobacco by $16 \mathrm{~h}$, therefore indicating that other effector proteins secreted via the hrp gene system contribute to the tobacco HR. A HR necrosis phenotype was observed in tobacco leaves after $24 \mathrm{~h}$ with our $h r c C$, $h r p G$, and $h r p N$ mutants. This late-stage necrotic response may be caused by pectic enzymes or other HR elicitors that are secreted from the bacteria.

We have utilized a microarray gene expression project with E. chrysanthemi 3937 to identify genes that are specifically upregulated when the bacteria are pathogenically engaged in plant leaves. A genome-sequencing project will also begin soon. As a consequence of the large number of new genes that will be discovered in these projects, we utilized the crossover PCR strategy to make precise gene knockouts, permitting definitive tests of their roles in virulence. Since entire ORFs or blocks of ORFs can be deleted using the crossover PCR strategy, problems with residual gene function that may be attendant in insertional mutagenesis strategies are avoided. The crossover PCR strategy also entails the incorporation of universal primer sequences that are useful in order to check mutant constructs by PCR and utilizes unique random 20 -mer barcode sequences for each mutant strain constructed (Fig. 1). The barcode strategy was devised by yeast researchers (Winzeler et al. 1999) and permits the use of competition assays in which mixtures of mutants and wild-type cells can be studied in the plant or other environments and each mutant in the mixture is quantitated by PCR using the appropriate barcode as a primer. The major negative features of the new strategy are costs for primers, PCR reactions, and time investment. For this reason, we used an in vitro Tn5 system for initial rapid mutant construction and employed the precise crossover PCR method to construct null mutations in selected genes of interest.

\section{MATERIALS AND METHODS}

Bacterial strains, plasmids, and media.

The bacterial strains and plasmids used in this study are listed in Table 1. E. chrysanthemi 3937 and mutant strains were stored at $-80^{\circ} \mathrm{C}$ in $15 \%$ glycerol and grown on LuriaBertani (LB) agar. Antibiotics used were kanamycin, $20 \mu \mathrm{g} / \mathrm{ml}$; tetracycline, $12.5 \mu \mathrm{g} / \mathrm{ml}$; and chloramphenicol, $20 \mu \mathrm{g} / \mathrm{ml}$. LB liquid and agar medium was used for bacterial culture.

\section{Electroporation of plasmids into E. chrysanthemi 3937.}

We previously used electrocompetent cells of strain EC16 prepared by successive washes with $10 \%$ glycerol at ice temperature. However, strain 3937 cells prepared with glycerol were found to lose transformation competence rapidly during storage at $-80^{\circ} \mathrm{C}$. We accordingly experimented to find more optimal conditions for preparing electrocompetent strain 3937 cells. The following procedure was devised and permitted the

Table 3. Disease index of Erwinia chrysanthemi 3937 wild-type and $h r c C$ and $h r p G$ mutant strains on variety Katja at 3 and 7 days after inoculation

\begin{tabular}{lcc}
\hline Bacterial strains $^{\mathbf{a}}$ & DI at $\mathbf{3}$ days $^{\mathbf{b}}$ & ${\text { DI at } \mathbf{7} \text { days }^{\mathbf{b}}}^{\mathbf{b}}$ \\
\hline Wild type & 1.5 & 3.9 \\
hrcC mutant & 0.1 & 1.2 \\
hrp $G$ mutant & 0.1 & 0.9 \\
\hline
\end{tabular}

${ }^{\mathrm{a}}$ Ten plants with a total of 10 leaves were used for each bacterial isolate.

${ }^{\mathrm{b}}$ The disease index (DI) was scored as follows: $0=$ no maceration symptoms, $1=$ less than $20 \%$ maceration of the total leaf, $2=20$ to $39 \%, 3=$ 40 to $59 \%, 4=60$ to $79 \%$, and $5=80$ to $100 \%$. storage of electrocompetent cells for several months with retention of reasonable transformation efficiency $\left(10^{5}\right.$ to $10^{6}$ transformants per $\mu \mathrm{g}$ of DNA).

A single colony of strain 3937 was grown in LB overnight (30 $\mathrm{ml}$ at $37^{\circ} \mathrm{C}$ with shaking), and the entire culture was added to $500 \mathrm{ml}$ of prewarmed LB medium in a 1-liter Erlenmeyer flask. The culture was grown at $37^{\circ} \mathrm{C}$ with rapid shaking. When the cell density reached 0.5 to 0.6 absorbance at $600 \mathrm{~nm}$, the flask was cooled on ice and the cells were pelleted in $250-\mathrm{ml}$ centrifuge bottles at $5,000 \times g$ for $5 \mathrm{~min}$. The cells were then suspended in approximately $150 \mathrm{ml}$ of ice cold wash buffer (10\% glycerol; $10 \%$ sucrose; $5 \mathrm{mM} \mathrm{N}$-2-hydroxyethylpiperazine- $N^{\prime}$-2-ethanesulfonic acid, $\mathrm{pH}$ 7.0) and the cells were pelleted at 7,500 $\times g$ for $5 \mathrm{~min}$. The supernatant was decanted and the cells were washed two additional times with approximately $150 \mathrm{ml}$ of ice cold wash buffer. The final pellet was suspended in approximately one cell volume of ice cold wash buffer and kept on ice. The competent cells were used directly for electroporation or frozen on dry ice and stored at $-80^{\circ} \mathrm{C}$ for future use.

For electroporation, 1 to $10 \mu \mathrm{l}$ of DNA (50 to $100 \mathrm{ng} / \mu \mathrm{l}$ ) in Tris-EDTA or water was mixed with $80 \mu$ of frozen/thawed or fresh electrocompetent strain 3937 cells in $0.2-\mathrm{cm}$ electroporation cuvettes on ice. The cells were electroporated with a BioRad electroporator (Bio-Rad, Hercules, CA, U.S.A.) at 12,500 volts $/ \mathrm{cm}, 200 \mathrm{ohms}$, and $25 \mu$ farads. LB $(0.6 \mathrm{ml})$ at room temperature was added to the cells, which were placed into microfuge tubes and shaken at $37^{\circ} \mathrm{C}$ for 1 to $2 \mathrm{~h}$. Transformation mixtures were plated on LB with the appropriate antibiotic and grown at $37^{\circ} \mathrm{C}$.

\section{Cloning of $\boldsymbol{h r p} G$ and $\boldsymbol{h r p N}$ and DNA manipulations.}

DNA sequences from E. chrysanthemi strain EC16 (GenBank accession no. L39897) were used to design primers for PCR amplification of the hrpG and $h r p N$ genes from E. chrysanthemi 3937. Kanamycin cassettes containing an AscI site were produced by PCR with vector pBBR1MCS-2 as a temlate (Kovach et al. 1995). For routine cloning, PCR fragments were cloned into the $3^{\prime} \mathrm{T}$ overhangs of pGEM-T Easy (Proega, Madison, WI, U.S.A.). Transformed JM-109 or DH5 $\alpha$ cells were plated on LB medium containing ampicillin and 5-bromo-4-chloro-3-indolyl- $\beta$-D-galactopyranoside (80 $\mu \mathrm{g} / \mathrm{ml}$ ), and white colonies were selected for the confirmation of plasmid constructs.

The strain 3937 hrpG gene containing its own promoter (cloned with primers HrpG A and HrpG D; Table 1) was subcloned into pRK415, permitting a complementation assay of the hrpG deletion mutant of E. chrysanthemi 3937. The FailSafe PCR Reaction System (Epicentre, Madison, WI, U.S.A.) containing DNA polymerase with proof-reading function was used for the PCR reaction. PCR amplification of E. chrysanthemi 3937 hrpN was performed with primers P1 and P2 (Table 1). The amplified fragment was confirmed

Table 4. Disease index of Erwinia chrysanthemi 3937 wild-type, hrpN, $\Delta p e l$, and $\Delta p e l$ hrpN strains on African violet variety Katja leaves at 1, 3, and 7 days after inoculation

\begin{tabular}{lccc}
\hline Bacterial strains $^{\mathbf{a}}$ & DI at 1 day $^{\mathbf{b}}$ & DI at 3 days & DI at 7 days \\
\hline Wild-type & 1.5 & 3.6 & 4.6 \\
hrpN mutant & 0.4 & 3.1 & 4.6 \\
spel mutant & 0.3 & 1.16 & 1.9 \\
Lpel hrpN mutant & 0.2 & 0.2 & 0.2 \\
\hline
\end{tabular}

a Twelve plants were used for each bacterial isolate.

$\mathrm{b}$ The disease index (DI) was scored as follows: $0=$ no maceration symptoms, $1=$ less than $20 \%$ maceration of the total leaf, $2=20$ to $39 \%, 3=$ 40 to $59 \%, 4=60$ to $79 \%$, and $5=80$ to $100 \%$. 
by sequencing. All other recombinant DNA techniques were carried out as described by Sambrook and colleagues (1989).

\section{Crossover PCR method for precise ORF deletions and construction of insertion mutant strains.}

The construction of gene knockouts of the hrpG and hrpN genes and the pelA-pemA cluster in E. chrysanthemi 3937 utilized a crossover PCR strategy (Fig. 1). In the first step, two different asymmetric PCR reactions were performed to generate fragments to the left (with primers A and B) and right (with primers $\mathrm{C}$ and $\mathrm{D}$ ) sides of the sequences targeted for deletion. Primer B was designed with a 20-base barcode at the $5^{\prime}$ end and a universal sequencing tag1 (U1), followed by 20 bases of homology to the region upstream of the targeted ORF. Primer C contained a 20-base barcode, an AscI restriction site, universal sequencing tag2 (U2), and 20 bases of DNA homologous to the strain 3937 downstream region of the targeted ORF (Fig. 1). The barcodes and universal tags were designed to facilitate the identification of specific E. chrysanthemi 3937 mutants in host plants inoculated with various mutants and wild-type bacteria by microarray analysis or real time PCR. Primers B and C were designed close to the ATG translation initiators and stop codons of target ORFs, but at least 15 bases inside the ORFs to account for possible gene overlaps.

In the second step of the crossover PCR gene knockout strategy, the left PCR fragment (Fig. 1, produced by primers A and B) and right PCR fragment (produced by primers C and D) were annealed at their complementary, overlapping barcode regions and further amplified by a second round of PCR with primers A and D. The final mutagenic PCR fragments were

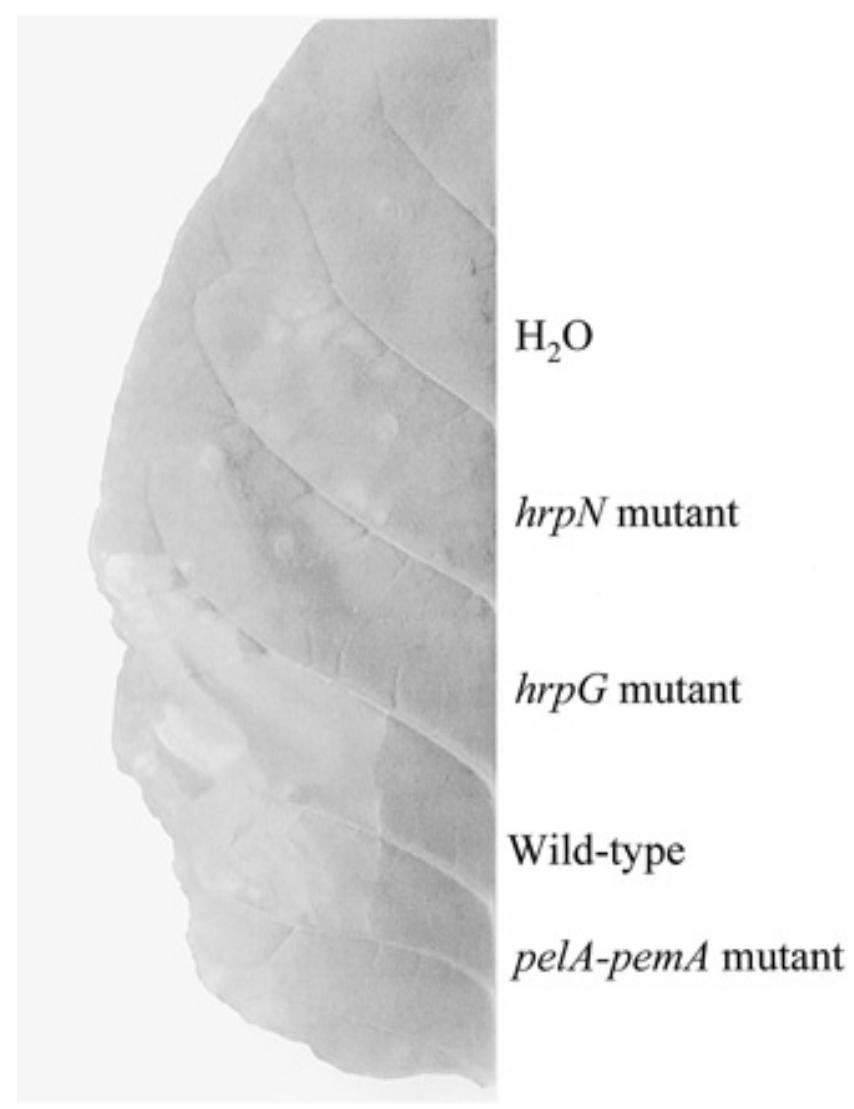

Fig. 4. Tobacco leaf panels infiltrated with wild-type Erwinia chrysanthemi 3937, pelA-pemA mutant, $h r p G$ mutant, or $\operatorname{rrpN}(h r p N:: \mathrm{km})$ mutant. Bacteria were suspended in water at a concentration of $5 \times 10^{8} \mathrm{CFU} / \mathrm{ml}$ and infiltrated into leaves with a 1-ml syringe. The leaf was photographed at $16 \mathrm{~h}$ after inoculation. cloned into the $3^{\prime} \mathrm{T}$ overhangs of pGEM-T Easy, a kanamycin gene was cloned into the $A s c I$ site, and the resulting mutagenic construct was recloned into the Not I site of $\mathrm{pKO}_{3}$. Following electroporation of the plasmid constructs into wild-type strain 3937 cells, kanamycin-resistant bacteria were grown on $5 \mathrm{ml}$ of low phosphate medium for $36 \mathrm{~h}$ at $28^{\circ} \mathrm{C}$ and then plated on LB medium containing kanamycin and 5\% sucrose (Ried and Collmer 1987). Sucrose-resistant colonies were tested for chloramphenicol sensitivity in order to select for $\mathrm{pKO}_{3}$-cured bacteria. Chromosomal DNA was isolated from putative mutant strains, and PCR was used to confirm the mutations using primers $\mathrm{A}$ and $\mathrm{D}$ in combination with the universal sequencing tags (Fig. 1). For construction of the $h r p G$ knockout strain, the $\mathrm{U} 2$ tag sequence was integrated into the primer hrpG $\mathrm{C}$ primer. For the $h r p N$ deletion strain $(h r p N:: k m$; Table 1), the U2 tag sequence was integrated into primer KmU2for.

The pectic enzyme gene cluster (pelA, pelE, pelD, paeY, and pemA) was deleted in strain 3937 by using the crossover PCR strategy. The pelA-pemA cluster from E. chrysanthemi 3937 was PCR-amplified with primers Pelfor1 and Pelrev1 (Table 1) and cloned into pGEM-T Easy to produce pPel. With plasmid pPel as a template, primers M13 forward/PelA B and M13 reverse/PemA $C$ were paired to generate PCR fragments for crossover deletion of the entire pelA-pemA region.

For construction of insertion mutants, mutagenesis with MUPR13 was performed as described previously (Boccara et al. 1988). Transduction with phage ØEC2 was done as described by Résibois and colleagues (1984).

\section{Virulence tests on African violet leaves.}

Plants of African violet (Saintpaulia ionantha) were obtained through the generosity of Holtkamp Greenhouses, Inc., Nashville, TN, U.S.A. Fully expanded leaves from greenhousegrown plants were used for inoculations. Two positions flanking the midrib and toward the upper end of the leaf were syringe-infiltrated with approximately $0.1 \mathrm{ml}$ of a bacterial suspension in distilled water. The infiltrated cell concentrations were determined by absorbance measurements at $600 \mathrm{~nm}$ and confirmed by the plating of appropriate dilutions. The virulence of bacterial strains was determined by visual estimation of leaf damage and quantitation of bacterial growth in the leaves. Concentrations of $10^{8} \mathrm{CFU} / \mathrm{ml}$ were infiltrated to determine the visual DI, and $10^{6} \mathrm{CFU} / \mathrm{ml}$ was used when bacterial populations in leaves were monitored.

Following inoculation of leaves, plants were kept in growth chambers at $28^{\circ} \mathrm{C}, 95 \%$ relative humidity, and a photoperiod of $16 \mathrm{~h}$. The progress of infection was followed every day for 1 week, and the DI was determined by estimation of the size of lesions according to the following scale: $0=$ no damage, $1=1$ to $19 \%$ maceration of the leaf, $2=20$ to $39 \%, 3=40$ to $59 \%, 4=$ 60 to $79 \%$, and $5=80$ to $100 \%$. The DI was calculated from these values according to the equation $\mathrm{DI}=\Sigma$ (leaves $\times n) /$ total number of leaves. Ten leaves on five plants were assayed for every mutant and compared with the wild-type control. The same was done for each plant variety tested.

\section{Enzyme and maceration assays.}

The pectate lyase activities of bacteria were determined on YC agar plates containing $0.7 \%$ sodium polygalacturonate (Keen et al. 1984). Potato tuber disks (cv. Russett Burbank) 12 $\mathrm{mm}$ in diameter and $5 \mathrm{~mm}$ thick, with a 4-mm-wide and 3-mmdeep well in the middle, were used for maceration assays (Keen et al. 1984). E. chrysanthemi 3937 cells were adjusted to 0.1 absorbance at $600 \mathrm{~nm}$ (approximately $10^{8} \mathrm{CFU} / \mathrm{ml}$, as confirmed by dilution plating). A 10-microliter volume of each bacterial cell suspension was added to each well of the potato disks. The inoculated potato disks were then placed in petri 
dishes at $28^{\circ} \mathrm{C}$, with 10 disks for each bacterial isolate. Maceration was assessed by probing the tissues at various time intervals with a small spatula to assess tissue integrity.

\section{Bacterial populations in inoculated leaves.}

To monitor population dynamics, bacterial suspensions of $10^{6} \mathrm{CFU} / \mathrm{ml}$ were infiltrated into African violet leaves. Leaf disks (4 $\mathrm{mm}$ in diameter) $1 \mathrm{~mm}$ away from the infiltration point were harvested at different intervals following infiltration and ground in sterile water, and the bacterial populations were determined by dilution plating. Eight leaves per bacterial isolate and four disks per leaf, with a total of eight replicate plants, were used for each sampling time.

\section{HR assay.}

Tobacco leaves (Nicotiana tabacum L. cv. Xanthi) were used for the HR assays. E. chrysanthemi 3937 and mutant strains were grown in LB broth at $28^{\circ} \mathrm{C}$ until mid-log phase and bacterial cells were washed with water and adjusted to a concentration of $5 \times 10^{8} \mathrm{CFU} / \mathrm{ml}$ in water. Fully expanded young tobacco leaves were infiltrated with bacteria and kept in a growth chamber at $70 \%$ humidity and $28^{\circ} \mathrm{C}$. Visible necrosis was determined at $16 \mathrm{~h}$ after inoculation.

\section{ACKNOWLEDGMENTS}

This work was supported by grants to N. T. Keen from the National Research Initiative of the USDA and to M. Boccara from the INRA. M. Gavilanes-Ruiz was supported by a sabbatical fellowship from DGAPA, UNAM, and CONACyT, Mexico. We would like to thank C. Picard and M. Rousseau for technical assistance in preliminary experiments, G. Boccara-Jones for comments on the manuscript, and our colleagues for support and advice. We gratefully acknowledge Holtkamp Greenhouses, Inc., Nashville, TN, U.S.A., for supplying African violet plants; Y. Ishino for writing software on barcode design; and D. A. Cooksey, D. E. Crowley, and J. Smith-Becker for helpful discussions on the manuscript.

\section{LITERATURE CITED}

Alfano, J. R., and Collmer, A. 1997. The type III (Hrp) secretion pathway of plant pathogenic bacteria: Trafficking harpins, Avr proteins, and death. J. Bacteriol. 179:5655-5662.

Alfano, J. R., Bauer, D. W., Milos, T. M., and Collmer, A. 1996. Analysis of the role of the Pseudomonas syringae pv. syringae HrpZ harpin in elicitation of the hypersensitive response in tobacco using functionally nonpolar hrpZ deletion mutations, truncated HrpZ fragments, and hrmA mutations. Mol. Microbiol. 19:715-724.

Arlat, M., Van Gijsegem, F., Huet, J. C., Pernollet, J. C., and Boucher, C. A. 1994. PopA1, a protein which induces a hypersensitivity-like response on specific petunia genotypes, is secreted via the hrp pathway of Pseudomonas solanacearum. EMBO (Eur. Mol. Biol. Organ.) J. 13: 543-553.

Barny, M.-A. 1995. Erwinia amylovora hrpN mutants, blocked in harpin synthesis, express a reduced virulence on host plants and elicit variable hypersensitive reactions on tobacco. Eur. J. Plant Pathol. 101:333340

Bauer, D. W., Bogdanove, A. J., Beer, S. V., and Collmer, A. 1994. Erwinia chrysanthemi hrp genes and their involvement in soft rot pathogenesis and elicitation of the hypersensitive response. Mol. PlantMicrobe Interact. 7:573-581.

Bauer, D. W., Wei, Z.-M., Beer, S. V., and Collmer, A. 1995. Erwinia chrysanthemi harpin ${ }_{E c h}$ : An elicitor of the hypersensitive response that contributes to soft-rot pathogenesis. Mol. Plant-Microbe Interact. 8: 484-491.

Beaulieu, C., Boccara, M., and van Gijsegem, F. 1993. Pathogenic behaviour of pectinase-defective Erwinia chrysanthemi mutants on different plants. Mol. Plant-Microbe Interact. 6:197-202.

Boccara, M., Diolez, A., Rouve, M., and Kotoujansky, A. 1988. The role of individual pectate lyases of Erwinia chrysanthemi 3937 in pathogenicity on saintpaulia plants. Physiol. Mol. Plant Pathol. 33:95-104.

Bogdanove, A. J., Bauer, D. W., and Beer, S. V. 1998. Erwinia amylovora secretes $d s p E$, a pathogenicity factor and functional $a v r E$ homolog, through the hrp (type III secretion) pathway. J. Bacteriol. 180:22442247.
Charkowski, A. O., Alfano, J. R., Preston, G., Yuan, J., He, S. Y., and Collmer, A. 1998. The Pseudomonas syringae pv. tomato Hrp W protein has domains similar to harpins and pectate lyases and can elicit the plant hypersensitive response and bind to pectate. J. Bacteriol. 180:5211-5217.

Cui, Y., Madi, L., Mukherjee, A., Dumenyo, C. K., and Chatterjee, A. K. 1996. The RsmA ${ }^{-}$mutants of Erwinia carotovora subsp. carotovora strain Ecc71 overexpress $h r p N_{E c c}$ and elicit a hypersensitive reactionlike response in tobacco leaves. Mol. Plant-Microbe Interact. 9:565573.

Franza, T., Sauvage, C., and Expert, D. 1999. Iron regulation and pathogenicity in Erwinia chrysanthemi 3937: Role of the Fur repressor protein. Mol. Plant-Microbe Interact. 12:119-128.

Galan, J. E., and Collmer, A. 1999. Type III secretion machines: Bacterial devices for protein delivery into host cells. Science 284:1322-1328.

Gaudriault, S., Malandrin, L., Paulin, J.-P., and Barny, M.-A. 1997. DspA, an essential pathogenicity factor of Erwinia amylovora showing homology with AvrE of Pseudomonas syringae, is secreted via the Hrp secretion pathway in a DspB-dependent way. Mol. Microbiol. 26: 1057-1069.

He, S. Y. 1998. Type III protein secretion systems in plant and animal pathogenic bacteria. Annu. Rev. Phytopathol. 36:363-392.

Hu, W., Yuan, J., Jin, Q.-L., Hart, P., and He, S. Y. 2001. Immunogold labeling of Hrp pili of Pseudomonas syringae pv. tomato assembled in minimal medium and in planta. Mol. Plant-Microbe Interact. 14:234241.

Hueck, C. J. 1998. Type III protein secretion systems in bacterial pathogens of animals and plants. Microbiol. Mol. Biol. Rev. 62:379-433.

Hugouvieux-Cotte-Pattat, N., and Robert-Baudouy, J. 1985. Lactose metabolism in Erwinia chrysanthemi. J. Bacteriol. 162:248-255.

Keen, N. T., Dahlbeck, D., Staskawicz, B., and Belser, W. 1984. Molecular cloning of pectate lysae genes from Erwinia chrysanthemi and their expression in Escherichia coli. J. Bacteriol. 159:825-831.

Keen, N. T., Tamaki, S., Kobayashi, D., and Trollinger, D. 1988. Improved broad-host-range plasmids for DNA cloning in gram-negative bacteria. Gene 70:191-197.

Kim, J. F., Wei, Z.-M., and Beer, S. V. 1997. The hrpA and hrpC operons of Erwinia amylovora encode components of a type III pathway that secretes harpin. J. Bacteriol. 179:1690-1697.

Kim, J. F., Ham, J. H., Bauer, D. W., Collmer, A., and Beer, S. V. 1998. The hrpC and hrpN operons of Erwinia chrysanthemi EC16 are flanked by $p l c A$ and homologs of hemolysin/adhesin genes and accompanying activator/transporter genes. Mol. Plant-Microbe Interact. 11:563-567.

Kovach, M. E., Elzer, P. H., Hill, D. S., Robertson, G. T., Farris, M. A. Roop, R. M., II, and Peterson, M. K. 1995. Four new derivatives of the broad-host-range cloning vector pBBR1MCS, carrying different antibiotic-resistance cassettes. Gene 166:175-176.

LeMattre, M., and Narcy, J. P. 1972. Une infection bacterienne nouvelle du Saintpaulia due a Erwinia chrysanthemi. C. R. Acad. Sci. 58:227231.

Link, A. J., Phillips, D., and Church, G. M. 1997. Methods for generating precise deletions and insertions in the genome of wild-type Escherichia coli: Application to open reading frame characterization. J. Bacteriol. 179:6228-6237.

López-Solanilla, E., Llama-Palacios, A., Collmer, A., García-Olmedo, F., and Rodríguez-Palenzuela, P. 2001. Relative effects on virulence of mutations in the sap, pel, and hrp loci of Erwinia chrysanthemi. Mol. Plant-Microbe Interact. 14:386-393.

Nasser, W., Bouillant, M. L., Salmond, G., and Reverchon, S. 1998 Characterization of the Erwinia chrysanthemi expl-expR locus directing the synthesis of two N-acyl-homoserine lactone signal molecules. Mol. Microbiol. 29:1391-1405.

Rantakari, A., Virtaharju, O., Vähämiko, S., Taira, S., Palva, E. T., Saarilahti, H. T., and Romantschuk, M. 2001. Type III secretion contributes to the pathogenesis of the soft-rot pathogen Erwinia carotovora: Partial characterization of the hrp gene cluster. Mol. PlantMicrobe Interact. 14:962-968.

Ratet, P., Schell, J., and Bruijn, F. J. 1988. MiniMulac transposons with broad host-range origins of conjugal transfer and replication designed for gene regulation studies in Rhizobiaceae. Gene 63:41-52.

Résibois, A., Colet, M., Faelen, M., Schoonejans, E., and Toussaint, A. 1984. PhiEC2, a new generalized transducing phage of Erwinia chrysanthemi. Virology 137:102-112.

Reverchon, S., Bouillant, M. L., Salmond, G., and Nasser, W. 1998. Integration of the quorum-sensing system in the regulatory networks controlling virulence factor synthesis in Erwinia chrysanthemi. Mol. Microbiol. 29:1407-1418.

Ried, J. L., and Collmer, A. 1987. An nptI-sacB-sacR cartridge for constructing directed, unmarked mutations in gram-negative bacteria by 
marker exchange-eviction mutagenesis. Gene 57:239-246.

Robert-Baudouy, J., Nasser, W., Condemine, G., Reverchon, S., Shevchik, V. E., and Hugouvieux-Cotte-Pattat, N. 2000. Pectic enzymes of Erwinia chrysanthemi, regulation and role in pathogenesis. Pages 221-268 in: Plant-Microbe Interactions. Vol. 5. G. Stacey and N. T. Keen, eds. American Phytopathological Society, St. Paul, MN, U.S.A.

Sambrook, J., Fritsch, E. F., and Maniatis, T. A. 1989. Molecular Cloning: A Laboratory Manual. 2nd ed. Cold Spring Harbor Laboratory, Cold Spring Harbor, NY, U.S.A.

Shevchik, V. E., and Hugouvieux-Cotte-Pattat, N. 1997. Identification of a bacterial pectin acetyl esterase in Erwinia chrysanthemi 3937. Mol. Microbiol. 24:1285-1301.

Shevchik, V. E., Boccara, M., Vedel, R., and Hugouvieux-Cotte-Pattat, N. 1998. Processing of the pectate lyase Pell by extracellular proteases of Erwinia chrysanthemi 3937. Mol. Microbiol. 29:1459-1469.

Winzeler, E. A., Shoemaker, D. D., Astromoff, A., Liang, H., Anderson,
K., Andre, B., Bangham, R., Benito, R., Boeke, J. D., Bussey, H., Chu, A. M., Connelly, C., Davis, K., Dietrich, F., Dow, S. W., EL Bakkoury, M., Foury, F., Friend, S. H., Gentalen, E., Giaever, G., Hegemann, J. H., Jones, T., Laub, M., Liao, H., Liebundguth, N., Lockhart, D. J., Lucau-Danila, A., Lussier, M., M'Rabet, N., Menard, P., Mittmann, M., Pai, C., Rebischung, C., Revuelta, J. L., Riles, L., Roberts, C. J., Ross-MacDonald, P., Scherens, B., Snyder, M., Sookhai-Mahadeo, S., Storms, R. K., Veronneau, S., Voet, M., Volckaert, G., Ward, T. R. Wysocki, R., Yen, G. S., Yu, K. X., Zimmermann, K., Philippsen, P., Johnston, M., and Davis, R. W. 1999. Functional characterization of the $S$. cerevisiae genome by gene deletion and parallel analysis. Science 285:901-906.

Yuan, J., Wei, W., Gopalan, S., Hu, W., Jin, Q., Plovanich-Jones, A., Muncie, L., and He, S. Y. 2000. hrp Genes of Pseudomonas syringae. Pages 1-20 in: Plant-Microbe Interactions. Vol. 5. G. Stacey and N. T. Keen, eds. American Phytopathological Society, St. Paul, MN, U.S.A. 